\title{
Industry 4.0 Technology Re-Engineering Impacts on Strategy Agility and SME Competitiveness in Malaysia
}

\author{
Paramasivan Lavinsaa* \\ Graduate School of Business \\ Universiti Sains Malaysia \\ Penang, Malaysia \\ lavinsaa@gmail.com
}

\author{
Hemalatha Somu \\ Graduate School of Business \\ Universiti Sains Malaysia \\ Penang, Malaysia \\ pkv7599@gmail.com
}

\author{
Noor Hazlina Ahmad \\ Graduate School of Business \\ Universiti Sains Malaysia \\ Penang, Malaysia \\ hazlina@usm.my
}

\author{
Nabsiah Abdul Wahid \\ Graduate School of Business \\ Universiti Sains Malaysia \\ Penang, Malaysia \\ nabsiah@usm.my
}

\begin{abstract}
Competitiveness is the key factor for manufacturing SMEs to increase the Malaysia economy. Competency of manufacturers to react with the changes driven industry 4.0 is now becomes imperative for the manufacturers to sustain Competitiveness. Hence, the main objective for this study is to assess the competitiveness levels, as well as to examine the relationship between industry 4.0 and Competitiveness, the function of industry 4.0 as mediating role. Specifically, the study integrates internal factor which are individual factors that consist of entrepreneurial orientation (innovativeness), organizational factor that consist of intellectual capital (structural capital) and external factor which is institutional factors, whereas SMEs competitiveness is treated as the dependent variable. The theories used to link all the mediating and independent variable is Resource-Based View (RBV) and Institutional theory. The study is quantitative based via survey questionnaire and responded by 162 SMEs manufacturers and analyses were carried out using SPSS and Smart-PLS software. This paper is one of the initial attempts to draw the attention towards the important role of management practices in industry 4.0, as most of the recent studies are discussing the technological aspect. This paper also suggests empirical and quantitative investigation on these management approaches in the context of industry 4.0. Through the finding, manufacturing SMEs are clearly aware and understand the engaging industry 4.0 to sustain the important of competitiveness in their business performance.
\end{abstract}

Keywords: competitiveness, entrepreneurial orientation, government, Industry 4.0, intellectual capital, manufacturing sector, Small and Medium Enterprises (SMEs)

\section{INTRODUCTION}

Small and Medium Enterprises (SMEs) are considered the backbone of an economy, and they play a major role in developing countries [1]. Based on a study by Gilpin [2], industrialization plays a key role in the economic growth of a nation. Globalization and the rapid growth of technology have paved the way for SMEs to increase their competitiveness. SMEs are the biggest contributors to the GDP in most countries [3], as small and medium enterprises (SMEs) contribute to the growth of nations [4]. In terms of employment, regardless of the degree of development and living standard in a country, SMEs are the biggest contributors to the employment of labor in a country. In the context of Malaysia, SMEs comprise $98.5 \%$ of the total establishments and have the potential to strengthen Malaysia's future economic development [5,6]. Based on the Annual Report [7] of SME FaCorp Malaysia, there were 920,624 business establishments in Malaysia of small and medium enterprises (SMEs) in the services sector, of which 809,126 SMEs formed the majority. The manufacturing sector is the second largest contributor in total SMEs in Malaysia with 47,698 establishments, forming a 5.3\% share in total SMEs, followed by a $4.3 \%$ in the construction sector $(39,158), 1.1 \%$ in the agriculture sector $(10,218)$, and $0.1 \%$ in the mining and quarrying sector (865). For the manufacturing sector, SMEs are defined as establishments with the number of full-time employees not exceeding 200 or sales turnover not exceeding RM50 million [6]. The manufacturing sector remains an important sector in the Malaysian economy [8,9]. As of 2017, Malaysia has recorded a total of RM1.07 trillion of approved investments in the manufacturing sector. The manufacturing sector in Malaysia contributes $80 \%$ of interregional trade, which is in goods, and only $20 \%$ is in services [10]. In this study, the focus is on the manufacturing sector in Malaysia because it has a large influence on the country's economy. Manufactured goods have become a key component for the service industries. Even though most economies are composed of service industries, these service industries are dependent on manufactured goods for their operation and the development of $\mathrm{R} \& \mathrm{D}$ for their technological progress [11].

Moreover, the manufacturing sector has become a key source of high paying jobs which, on average, pay $9 \%$ more in wages and benefits than jobs in the overall economy [12]. This fact highlights the importance that the manufacturing sector serves as an important source of jobs for individuals at many skill levels. Manufacturing sector for Malaysian Economy has become the major sector in generating employment opportunities as well. From this, it shows the influence on infrastructure development, job creation, and 
contribution to gross domestic product (GDP). To examine the effects of entrepreneurial orientation on innovativeness and intellectual capital on social structure and institutional factor on government support which will enhancing SME competitiveness in Malaysia through the mediating role of industry 4.0 .

\section{A. Background of Studies}

The importance of the manufacturing sector, as discussed in the previous section, through promoting competitiveness could be possible in order to maximize economic efficiency to achieve the nation's productivity. A study conducted by Jomo [13] showed that manufacturing SMEs had been recognized as one of the crucial sectors to improve the Malaysian economy. In order for Malaysia to achieve a high-income economy by 2025, the manufacturing sector needs to boost competitiveness in order to face the dynamic global environment [14]. The manufacturing production in Malaysia had been decreasing due to the output growth slowing, and new orders were failing to expand, according to Trading economics (2019). It was not a good start for Malaysian manufacturing sector in 2019 according to Malaysia's Purchasing Manager Index (PMI) as new orders have also been declining sharply since December 2018 up to now. Furthermore, Malaysian SMEs are not competitive in conducting their businesses. Hence, Malaysian entrepreneurs are slow in reacting to environmental changes and robust competition. In order to survive in a contemporary business setting, SMEs need to focus along the way to overcome the challenges and try to develop their competitiveness position [15]. Some other researchers also pointed out that improvement to competitiveness processes and rapid changes are primary elements of a company's success in the market [16]. However, one of the biggest challenges facing manufacturing SMEs are challenges require continuous innovation and learning, which is dependent on people and enterprise's capabilities for SMEs in Malaysia to be competitiveness.

\section{MATERIALS AND METHODS}

The study used a quantitative research method using a cross-sectional study which use random sampling. The study method adapted a questionnaire survey. The development of the questionnaire was done through a pretest phase. To test the hypotheses, we employed a survey of firms in Malaysia that had been engaged in strategic alliances. An English-language version of the questionnaire was first developed and then back-translated to Malay. To ensure the content and face validity of the measures, 5 interviews were conducted with two academic expert (Professor) from Universiti and three experts from manufacturing CEO was carried out. Based on the feedback of these respondents, we refined the measurement items of the questionnaire. To ensure conceptual equivalence and accuracy, the Malay version of the questionnaire was translated into English and then back-translated into Malay. The population and sample that have been used for hypothesis testing were the founder/owner/manager of the small and medium enterprises (SMEs) which drawn from the manufacturing sectors in Semanjung Malaysia through an online survey. The surveyed firms were selected from the current available list given by FFM (Federation Manufacturing Malaysia). We randomly selected 500 firms from FMM list. The sample frame includes firms from various high-tech and manufacturing industries.

The basic research design utilized for this study was a survey design. This study will stress on data obtained through primary data collection. The collection of primary data was accomplished through the use of a google and mail survey instrument. This instrument was used to collect information from questionnaires answered by the founder/owner/manager of the firms who are qualified to answer all the questions given.

To maximize the data accuracy and reliability, the study used Huber and Power's [17] guidelines on how to get quality data from single informants? Entrepreneurial orientation (EO) is normally viewed from the perspective of the CEO $[18,19]$, and CEOs are typically the well-versed persons regarding their overall business strategies and situations [20]. Likert scales were used to minimize executive response time and effort [21]. A five-point scale and seven-point scale has been adopted because research indicates can reduce bias from respondent.

Using mail survey as a methodology instrument is not only cost effective but it is also appropriate for a relatively large sample. The questionnaires were mail to the respondents on the 1st Dec 2018. After 3 months of followup, we managed to get 162 responses from 500 questionnaires sent out, which made up $32.4 \%$ response rate.

\section{RESULTS}

The study is quantitative based via survey questionnaire and responded by 162 SMEs manufacturers and analyses were carried out using SPSS and Smart-PLS software. The respondents of this study are the entrepreneurs from manufacturing SMEs in Malaysia and the list of these SMEs is listed in Federation of Malaysian Manufactures (FMM) Directory 2018. The data collection was conducted over 3 month's period. In addition, 205 companies are contacted and convinced to participate in the primary survey. Besides that these company have responded the questionnaire thought google link were sent to their emails. The actual administration of questionnaire was started from Dec 2018 until Feb 2019. Out of 205 companies, 182 SMEs connected with manufacturing sector have sent replies during the above said period. However 162 questionnaires were completed in all aspects while 20 questionnaires were not fulling the inclusion criteria and are not considered for the data analysis.

Table 1 revealed that $\mathrm{H} 1$ was also found supported as entrepreneurial orientation (EO) innovativeness has significant positive influence on industry 4.0 at $(\beta=0.166$, $\mathrm{t}$-value $=2.350, \mathrm{p}>0.01)$. The government has significant positive influence on industry $4.0(\beta=0.355$, $\mathrm{t}$-value $=$ 4.225, p > 0.001). Hence, hypothesis H3 was found supported. H4 was also found supported as industry 4.0 has significant positive influence on Malaysian manufacturing 
SMEs at $(\beta=0.330, \mathrm{t}$-value $=4.672, \mathrm{p}>0.01)$. The intellectual capital (IC) social structure has significant positive influence on industry $4.0(\beta=-0.046$, $\mathrm{t}$-value $=$ $0.600, p>0.05)$ but the $p$-value more than $5 \%$. Therefore, hypothesis $\mathrm{H} 2$ was found not supported.

TABle 1. SignificAnCE OF DiRECT EFFECTS PATH COEFFICIENTS $(n=162)$

\begin{tabular}{|c|c|c|}
\hline Hypothesis & Path & Result \\
\hline H1 & EOIN -> IND4.0 & Supported \\
\hline H2 & ICST -> IND4.0 & Not Supported \\
\hline H3 & GS -> IND4.0 & Supported \\
\hline H4 & IND4.0 -> SMEC & Supported \\
\hline
\end{tabular}

This is indirect effect which are H5, EOIN -> IND4.0 -> SMEC $(\beta=0.055$, t-value $=2.113, \mathrm{p}<0.05)$ and H7, GS -> AGL $->\operatorname{SMEC}(\beta=0.067$, t-value $=2.557, \mathrm{p}>0.05)$ were found supported. Besides that, H6, ICST $\rightarrow$ AGL $->$ SMEC $(\beta=0.075, \mathrm{t}$-value $=1.976, \mathrm{p}>0.01)$; were found not supported (Table 2).

TABLE 2. SignificANCE OF INDIRECT EFFECTS PATH COEFFICIENTS $(n=162)$

\begin{tabular}{|c|c|c|}
\hline Hypothesis & Path & Result \\
\hline H5 & EOIN -> IND4.0 -> SMEC & Supported \\
\hline H6 & ICST -> IND4.0 -> SMEC & $\begin{array}{c}\text { Not } \\
\text { Supported }\end{array}$ \\
\hline H7 & GS -> IND4.0 -> SMEC & Supported \\
\hline \multicolumn{2}{|r}{ Note: *p $<0.05, \mathrm{t}>1.96, * * p<0.01, \mathrm{t}>2.58$ (two-tailed) } \\
\hline
\end{tabular}

\section{DISCUSSION}

Identifying the factor that contributes to the SMEs competitiveness will help the sustainability of SMEs in the Malaysia. It is highlighted that the key factor in which SMEs should be aware of individual that were entrepreneurial orientation and organizational factors that were intellectual capital have important role in enhancing SMEs competitiveness. Thus, manufacturing SMEs in Malaysia should be conscious of the importance of competitiveness in ensuring their survival and sustainability in the industry arena. Foremost, this result provide insights to the Malaysian Government had various assistance programmes for manufacturing SMEs in Malaysia. Hence, with all the assistance programmes manufacturing SMEs should eliminate the perception that it is difficult to get support from the government. Based on the findings of this study, manufacturing SMEs in Malaysia are now aware of the importance in engaging in industry 4.0 to increase SMEs Competitiveness in Malaysia hence there are no excuses for them to ignore that. Through this study, manufacturing SMEs will be aware of the strategies and actions that will ensure their competitiveness.

\section{CONCLUSION}

This study found that three out of four variables have significant influence on the industry 4.0 and consequently, industry 4.0 affect the SMEs competitiveness. Meanwhile the one variables (ICST) did have not significant relationship with Industry 4.0. This study found that two out of three variables have significant influence on the when Industry 4.0 mediates the relationship between IV and DV; and consequently, industry 4.0 affect the SMEs competitiveness. Meanwhile the one variables (ICST) did have not significant relationship with industry 4.0. In conclusion, major finding of the study is that the entrepreneurial orientation, intellectual capital, government support barriers have a differential influence on the competitiveness among manufacturing SMEs in Malaysia. Besides, the industry 4.0 variable that has been introduced in this study is prevalence to increase competitiveness among manufacturing SMEs in Malaysia. Through the results achieved, manufacturing SMEs are clearly aware and understand the engaging industry 4.0 to sustain the important of competitiveness in their business performance. Manufacturing SMEs are now aware of their potential of industry 4.0 and the effect on their business practices. Through this study, manufacturing SMEs able to overcome the challenges and take proper action to increase the competitiveness and be the market leader.

\section{REFERENCES}

[1] C. Sommer, Drivers and Constraints for Adopting Sustainability Standards in Small and Mediumsized Enterprises (SMEs), Deutsches Institut fur Entwicklungspolitik, 2017

[2] R. Gilpin, The Challenge of Global Capitalism: The World Economy in the 21st Century, Princeton: Princeton University Press, 2018

[3] H. Kopnina and J. Blewitt, "Towards a circular economy," Sustainable Business, 2nd Edition, vol. 240, 2018

[4] J. Obi, A. S. Ibidunni, A. Tolulope, M. A. B. Olokundun, Amaihian, , T. T. Borishade, and P. Fred, "Contribution of small and medium enterprises to economic development: Evidence from a transiting economy", Data in brief, vol. 18, pp. 835-839, 2018

[5] SMEinfo. Here's Why SME Matters in Malaysia. Available from: http://www.smeinfo.com.my/profile-of-smes [Accessed 15 July 2019]

[6] SME Corp. Here's SME Definitions. Available from: http://www.smecorp.gov.my/index.php/en/policies/2015-12-21-0909-49/sme-definition [Accessed 10 July 2019]

[7] Annual Report of SME Corp Malaysia. Here's SME Annual Report 2017/18. Available from: http://www.smecorp.gov.my/index.php/en/laporan-tahunan/3342laporan-tahunan-pks-2017-18 [Accessed 10 July 2019]

[8] NST Business. Here's MALAYSIA breaches RM1 trillion total trade in just seven months. Available from: https://www.nst.com.my/business/2017/09/276948/malaysiabreaches-rm1-trillion-total-trade-just-seven-months [Accessed 10 Jun 2019]

[9] NST Business. Here's The Changing landscape of manufacturing sector. Available from: https://www.nst.com.my/business/2017/09/282055/changinglandscape-manufacturing-sector [Accessed 10 July 2019]

[10] Y. Wu, The Economics of the East Asia Steel Industries: Production, Consumption and Trade, Routledge, 2019

[11] S. M. H. S. Khairuddin, Z. H. Qureshi, R. A. Wahid, S. Tehseen, Z. H. Pathan, and M. R. Khan, "A conceptual study on contingent impact of external integration on innovation sme business success relationship," Int. Journal of Financial Research, vol. 10, 2019

[12] X. Ding, T. C. Fort, S. J. Redding, and P. K. Schott, "Structural change within versus across firms: Evidence from the United States," Working Paper Harvard University, 1, 4.5.

[13] K. S. Jomo, C. Y. Chung, B. C. Folk, I. Ul-Haque, P. Phongpaichit, B. Simatupang, and M. Tateishi, Southeast Asia's Misunderstood 
Miracle: Industrial Policy and Economic Development in Thailand, Malaysia and Indonesia, Boulder: Westview Press, 1997

[14] T. Im, and K. Hartley, "Aligning needs and capacities to boost government competitiveness," Public Organization Review, vol. 19(1), 119-137, 2019

[15] M. C. Suciu and D. F Năsulea, Intellectual Capital and Creative Economy as Key Drivers for Competitiveness Towards a Smart and Sustainable Development: Challenges and Opportunities for Cultural and Creative Communities, In Intellectual Capital Management as a Driver of Sustainability (pp. 67-97). Springer, Cham, 2019

[16] I. Petrov, V Kharitonov, and M. Polyakova, Procedure for Evaluating Competitiveness of Production Processes. In Materials Science Forum, vol. 946, pp. 726-731. Trans Tech Publications relationship: A longitudinal analysis. Journal of Business Venturing, 10, 43-58, 2019

[17] G. P. Huber and D. J. Power, "Retrospective reports of strategic level managers: Guidelines for increasing their accuracy," Strategic Management Journal, vol. 6, pp. 171-180, 1985

[18] J. G. Covin and D. P. Slevin, "Strategic management of small firms in hostile and benign environments," Strategic Management Journal, vol. 10, pp. 75-87, 1989

[19] J. Wiklund and D. Shepherd, "Knowledge-based resources, entrepreneurial orientation, and the performance of small and medium sized business," Strategic Management Journal, vol. 24(13), pp. 1307,2003

[20] S. A. Zahraand J. G. Covin, "Contextual influences on the corporate entrepreneurship-performance relationship: A longitudinal analysis," Journal of Business Venturing, vol. 10(1), pp. 43-58, 1995

[21] G. Knight and S. Cavusgil, "Innovation, organizational capabilities, and the born-global firm," Journal of International Business Studies, vol. 35, pp. 124-141, 2004 